\title{
LEVEL II SCOUR ANALYSIS FOR BRIDGE 35 (BRNATH00680035) on TOWN HIGHWAY 68, crossing LOCUST CREEK, BARNARD, VERMONT
}

U.S. Geological Survey Open-File Report 96-306

Prepared in cooperation with

VERMONT AGENCY OF TRANSPORTATION and

FEDERAL HIGHWAY ADMINISTRATION 


\section{LEVEL II SCOUR ANALYSIS FOR BRIDGE 35 (BRNATH00680035) on TOWN HIGHWAY 68, crossing LOCUST CREEK, BARNARD, VERMONT}

By MICHAEL A. IVANOFF and MATTHEW A. WEBER

U.S. Geological Survey Open-File Report 96-306

Prepared in cooperation with

VERMONT AGENCY OF TRANSPORTATION and

FEDERAL HIGHWAY ADMINISTRATION 


\title{
U.S. DEPARTMENT OF THE INTERIOR BRUCE BABBITT, Secretary
}

\author{
U.S. GEOLOGICAL SURVEY \\ Gordon P. Eaton, Director
}

For additional information write to:

District Chief

U.S. Geological Survey 361 Commerce Way

Pembroke, NH 03275
Copies of this report may be purchased from:

U.S. Geological Survey Earth Science Information Center Open-File Reports Section Box 25286, MS 517 Federal Center

Denver, CO 80225 


\section{CONTENTS}

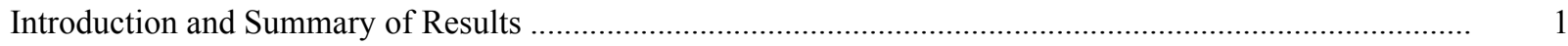

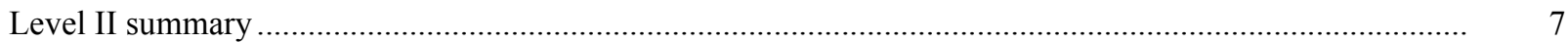

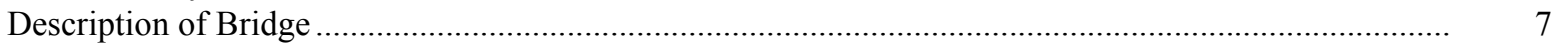

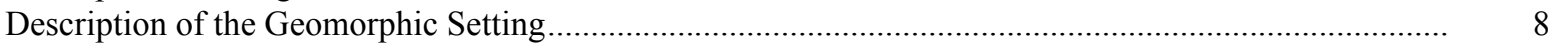

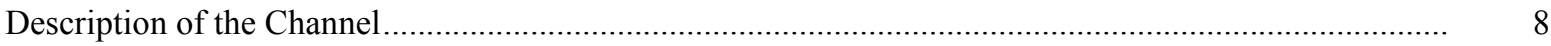

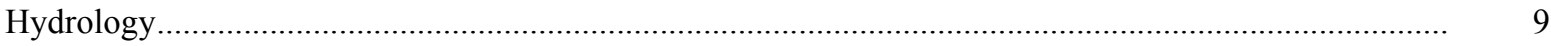

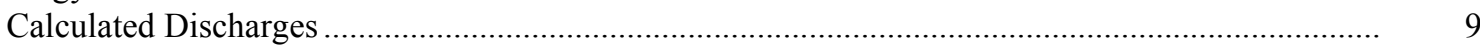

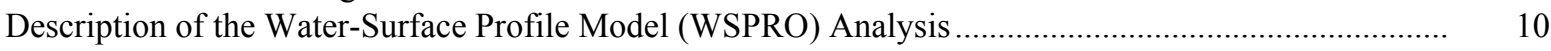

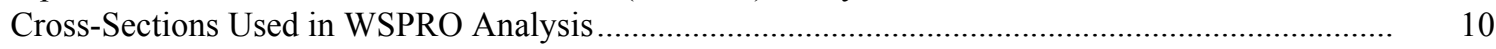

Data and Assumptions Used in WSPRO Model ...................................................................... 11

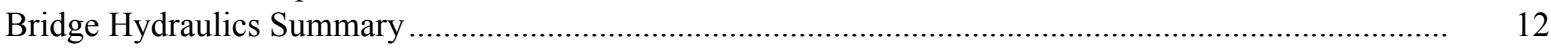

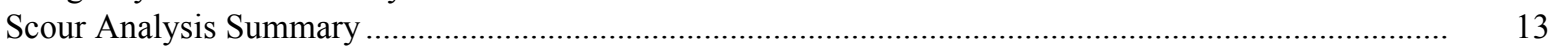

Special Conditions or Assumptions Made in Scour Analysis ...................................................... 13

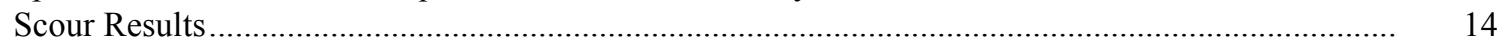

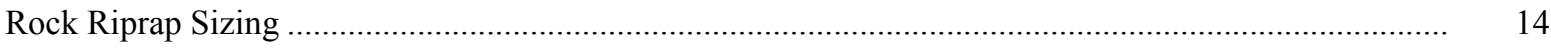

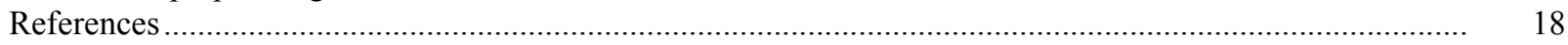

Appendixes:

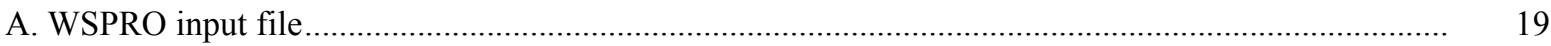

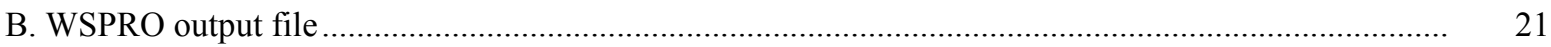

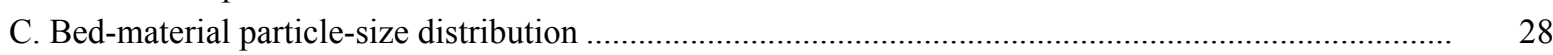

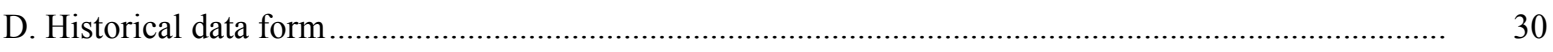

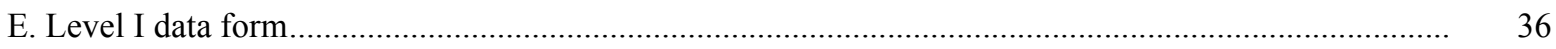

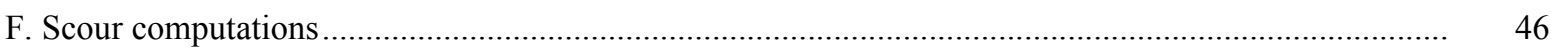

\section{FIGURES}

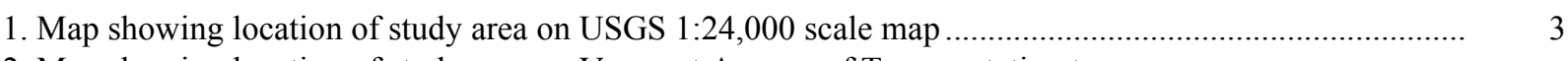

2. Map showing location of study area on Vermont Agency of Transportation town

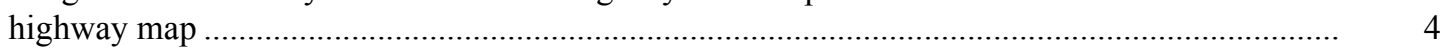

3. Structure BRNATH00680035 viewed from upstream (September 27, 1994) ....................................... 5

4. Downstream channel viewed from structure BRNATH00680035 (September 27, 1994). ...................... 5

5. Upstream channel viewed from structure BRNATH00680035 (September 27, 1994) ................................ 6

6. Structure BRNATH00680035 viewed from downstream (September 27, 1994) .................................. 6

7. Water-surface profiles for the 100- and 500-year discharges at structure

BRNATH00680035 on Town Highway 68, crossing Locust Creek,

Barnard, Vermont.

8. Scour elevations for the 100- and 500-year discharges at structure

BRNATH00680035 on Town Highway 68, crossing Locust Creek,

Barnard, Vermont.

\section{TABLES}

1. Remaining footing/pile depth at abutments for the 100-year discharge at structure

BRNATH00680035 on Town Highway 68, crossing Locust Creek,

Barnard, Vermont

2. Remaining footing/pile depth at abutments for the 500-year discharge at structure

BRNATH00680035 on Town Highway 68, crossing Locust Creek,

Barnard, Vermont.

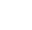

5

6

6




\begin{tabular}{|c|c|c|}
\hline Multiply & By & To obtain \\
\hline \multicolumn{3}{|c|}{ Length } \\
\hline inch (in.) & 25.4 & millimeter (mm) \\
\hline foot $(\mathrm{ft})$ & 0.3048 & meter $(\mathrm{m})$ \\
\hline mile (mi) & 1.609 & kilometer (km) \\
\hline \multicolumn{3}{|c|}{ Slope } \\
\hline foot per mile ( $\mathrm{ft} / \mathrm{mi})$ & 0.1894 & meter per kilometer $(\mathrm{m} / \mathrm{km})$ \\
\hline \multicolumn{3}{|c|}{ Area } \\
\hline square mile $\left(\mathrm{mi}^{2}\right)$ & 2.590 & square kilometer $\left(\mathrm{km}^{2}\right)$ \\
\hline \multicolumn{3}{|c|}{ Volume } \\
\hline cubic foot $\left(\mathrm{ft}^{3}\right)$ & $\begin{array}{l}0.02832 \\
\text { Velocity and Flow }\end{array}$ & cubic meter $\left(\mathrm{m}^{3}\right)$ \\
\hline foot per second (ft/s) & 0.3048 & meter per second $(\mathrm{m} / \mathrm{s})$ \\
\hline cubic foot per second $\left(\mathrm{ft}^{3} / \mathrm{s}\right)$ & 0.02832 & cubic meter per second $\left(\mathrm{m}^{3} / \mathrm{s}\right)$ \\
\hline $\begin{array}{l}\text { cubic foot per second per } \\
\text { square mile } \\
{\left[\left(\mathrm{ft}^{3} / \mathrm{s}\right) / \mathrm{mi}^{2}\right]}\end{array}$ & 0.01093 & $\begin{array}{l}\text { cubic meter per } \\
\text { second per square } \\
\text { kilometer }\left[\left(\mathrm{m}^{3} / \mathrm{s}\right) / \mathrm{km}^{2}\right]\end{array}$ \\
\hline
\end{tabular}

OTHER ABBREVIATIONS

$\begin{array}{lrlr}\mathrm{BF} & \text { bank full } & \text { LWW } & \text { left wingwall } \\ \mathrm{cfs} & \text { cubic feet per second } & \text { MC } & \text { main channel } \\ \mathrm{D}_{50} & \text { median diameter of bed material } & \text { RAB } & \text { right abutment } \\ \mathrm{DS} & \text { downstream } & \text { RABUT } & \text { face of right abutment } \\ \mathrm{elev} & \text { elevation } & \text { RB } & \text { right bank } \\ \mathrm{f} / \mathrm{p} & \text { flood plain } & \text { ROB } & \text { right overbank } \\ \mathrm{ft} & \text { square feet } & \text { RWW } & \text { right wingwall } \\ \mathrm{ft} / \mathrm{ft} & \text { feet per foot } & \text { TH } & \text { town highway } \\ \mathrm{JCT} & \text { junction } & \text { UB } & \text { under bridge } \\ \mathrm{LAB} & \text { left abutment } & \text { US } & \text { upstream } \\ \mathrm{LABUT} & \text { face of left abutment } & \text { USGS } & \text { United States Geological Survey } \\ \text { LB } & \text { left bank } & \text { VTAOT Vermont Agency of Transportation } \\ \text { LOB } & \text { left overbank } & \text { WSPRO } & \text { water-surface profile model }\end{array}$

In this report, the words "right" and "left" refer to directions that would be reported by an observer facing downstream. Sea level: In this report, "sea level" refers to the National Geodetic Vertical Datum of 1929-- a geodetic datum derived from a general adjustment of the first-order level nets of the United States and Canada, formerly called Sea Level Datum of 1929.

In the appendices, the above abbreviations may be combined. For example, USLB would represent upstream left bank. 


\title{
LEVEL II SCOUR ANALYSIS FOR BRIDGE 35 (BRNATH00680035) ON TOWN HIGHWAY 68, CROSSING LOCUST CREEK, BARNARD, VERMONT
}

\author{
By Michael A. Ivanoff and Matthew A. Weber
}

\section{INTRODUCTION AND SUMMARY OF RESULTS}

This report provides the results of a detailed Level II analysis of scour potential at structure BRNATH00680035 on town highway 68 crossing Locust Creek, Barnard, Vermont (figures 1-8). A Level II study is a basic engineering analysis of the site, including a quantitative analysis of stream stability and scour (U.S. Department of Transportation, 1993). A Level I study is included in Appendix E of this report. A Level I study provides a qualitative geomorphic characterization of the study site. Information on the bridge available from VTAOT files was compiled prior to conducting Level I and Level II analyses and can be found in Appendix D.

The site is in the Green Mountain physiographic province of central Vermont in the town of Barnard. The 24.1- $\mathrm{mi}^{2}$ drainage area is in a predominantly rural and forested basin. In the vicinity of the study site, the banks have woody vegetation coverage.

In the study area, Locust Creek has an incised sinuous channel with a slope of approximately $0.0133 \mathrm{ft} / \mathrm{ft}$, an average channel top width of $58 \mathrm{ft}$ and an average channel depth of $5 \mathrm{ft}$. The predominant channel bed material is cobble $\left(\mathrm{D}_{50}\right.$ is $135 \mathrm{~mm}$ or $0.443 \mathrm{ft}$ ). The geomorphic assessment at the time of the Level I and Level II site visits on September 21 and 27, respectively, with a check on December 15, 1994, indicated that the reach was stable.

The town highway 68 crossing of Locust Creek is a 30-ft-long, one-lane bridge consisting of one 28-foot concrete slab type superstructure (Vermont Agency of Transportation, written commun., August 23, 1994). The bridge is supported by vertical, concrete abutments with wingwalls. The channel is not skewed to the opening and the opening-skewto-roadway is zero degrees.

A scour hole $0.5 \mathrm{ft}$ deeper than the mean thalweg depth was observed along the right abutment and downstream right wingwall during the Level I assessment. The only scour protection measure in place at the site was type- 2 stone fill (less than 36 inches diameter) at the left abutment and wingwalls except the downstream right wingwall. Additional details describing conditions at the site are included in the Level II Summary and Appendices D and $\mathrm{E}$. 
Scour depths and rock rip-rap sizes were computed using the general guidelines described in Hydraulic Engineering Circular 18 (Richardson and others, 1993). Total scour at a highway crossing is comprised of three components: 1) long-term streambed degradation; 2) contraction scour (due to accelerated flow caused by a reduction in flow area at a bridge) and; 3) local scour (caused by accelerated flow around piers and abutments). Total scour is the sum of the three components. Equations are available to compute depths for contraction and local scour and a summary of the results of these computations follows.

Contraction scour for all modelled flows ranged from 0.0 to $3.4 \mathrm{ft}$. The worst-case contraction scour occurred at the incipient overtopping discharge, which was between the 100- and 500-year discharges. Abutment scour ranged from 11.5 to $25.7 \mathrm{ft}$. with the worstcase scenario occurring at the 500-year discharge. Additional information on scour depths and depths to armoring are included in the section titled "Scour Results". Scouredstreambed elevations, based on the calculated scour depths, are presented in tables 1 and 2. A cross-section of the scour computed at the bridge is presented in figure 8. Scour depths were calculated assuming an infinite depth of erosive material and a homogeneous particlesize distribution.

It is generally accepted that the Froehlich equation (abutment scour) gives "excessively conservative estimates of scour depths" (Richardson and others, 1993, p. 48). Many factors, including historical performance during flood events, the geomorphic assessment, scour protection measures, and the results of the hydraulic analyses, must be considered to properly assess the validity of abutment scour results. Therefore, scour depths adopted by VTAOT may differ from the computed values documented herein, based on the consideration of additional contributing factors and experienced engineering judgement. 


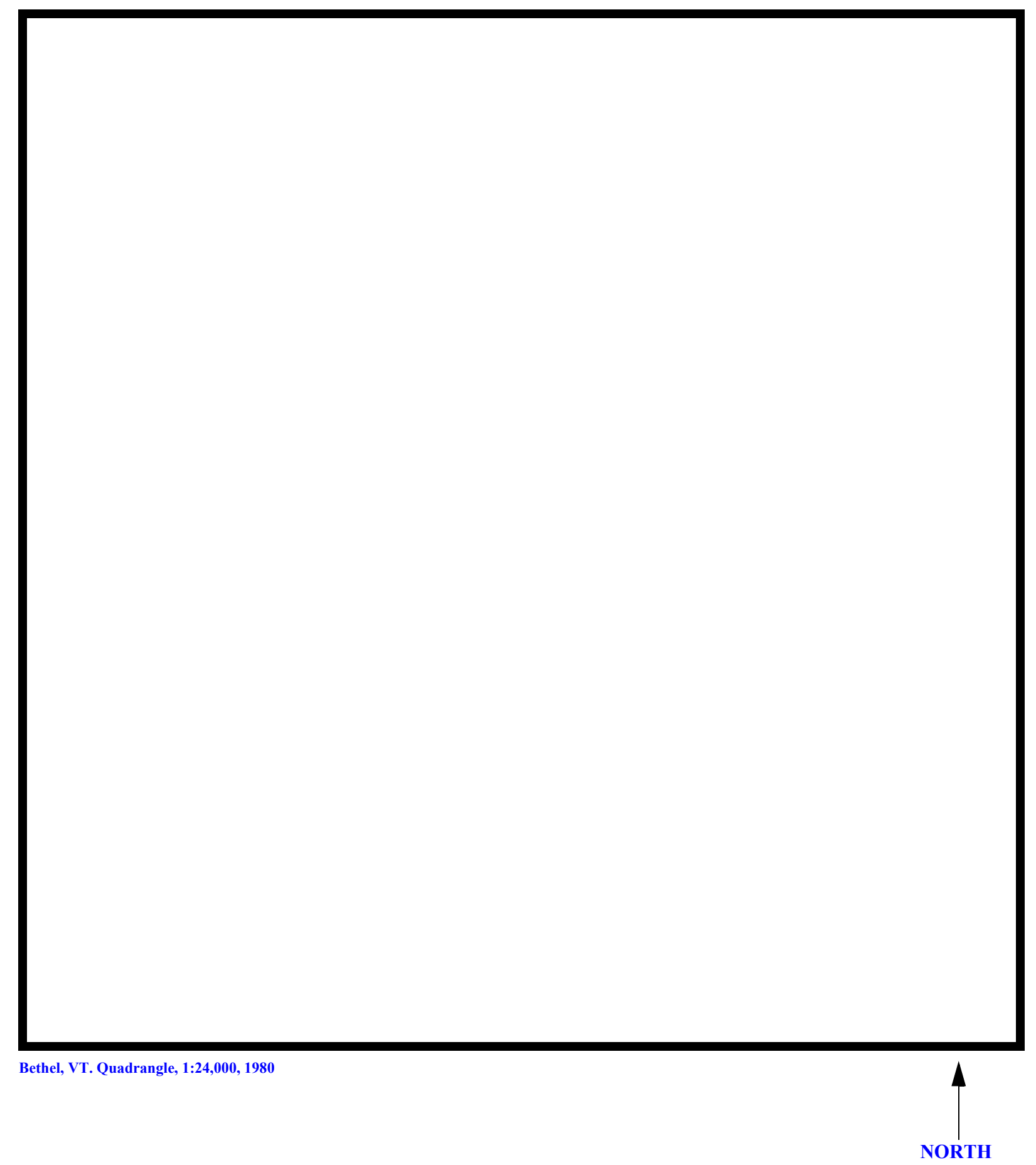

Figure 1. Location of study area on USGS 1:24,000 scale map. 
Figure 2. Location of study area on Vermont Agency of Transportation town highway map. 

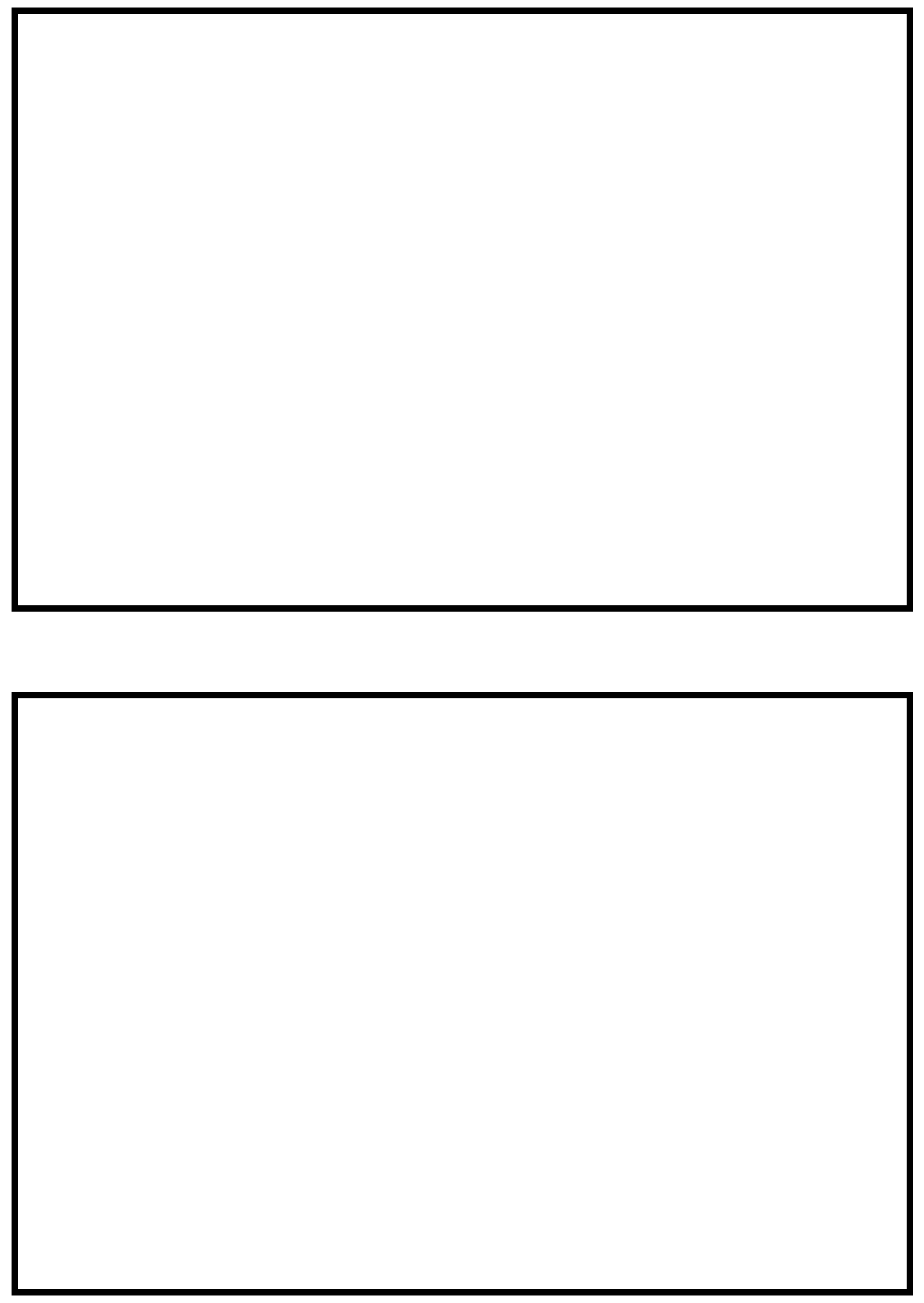

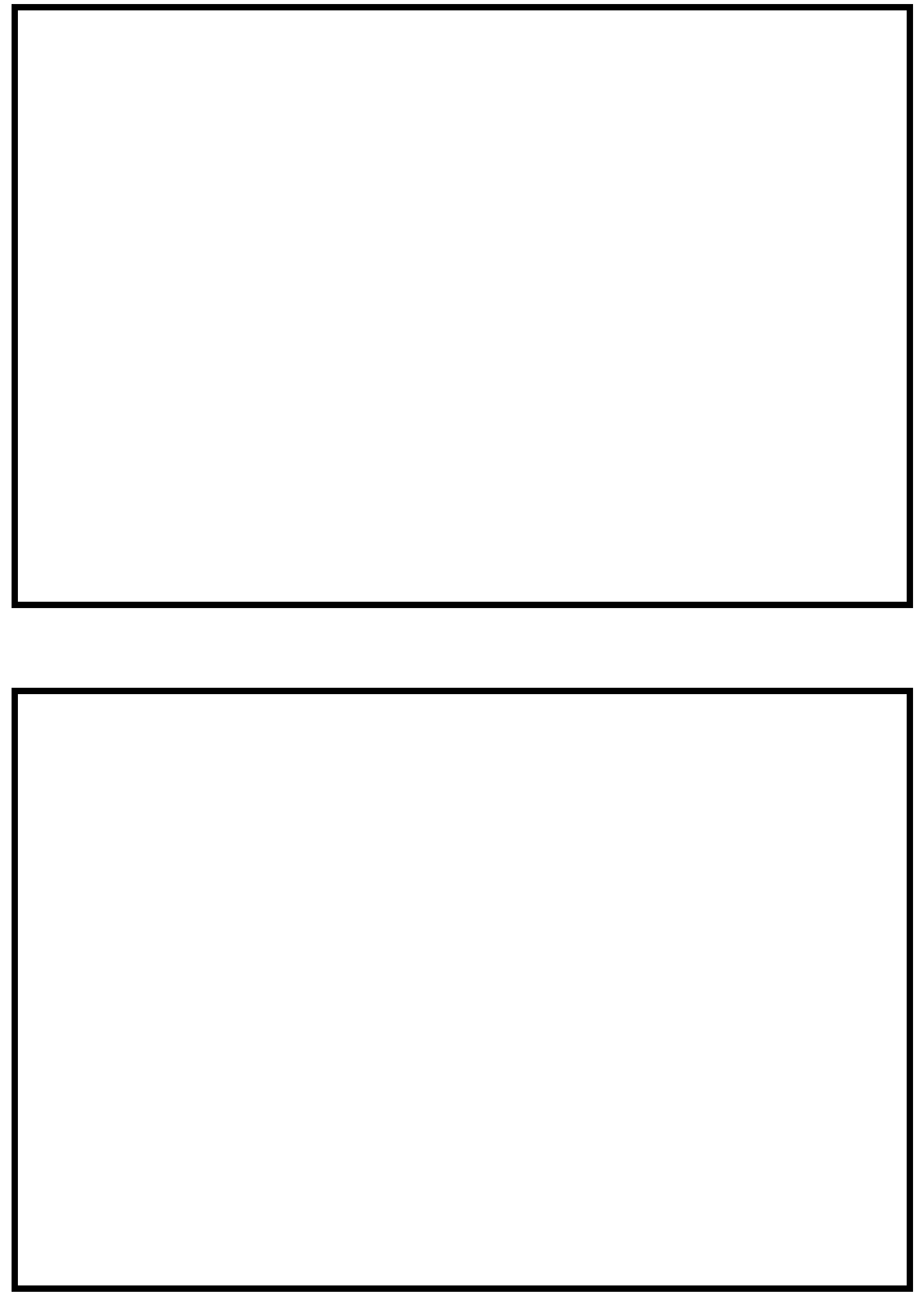


\section{LEVEL II SUMMARY}

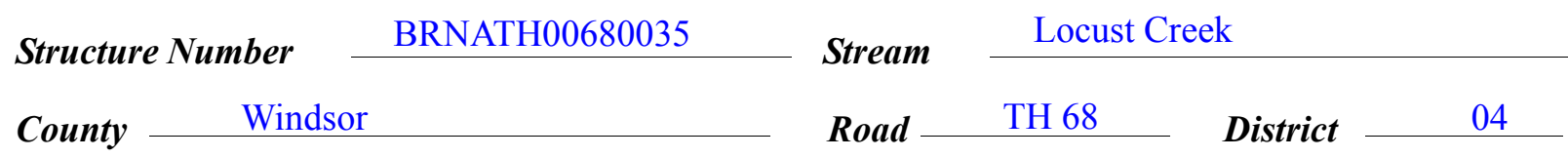

\section{Description of Bridge}

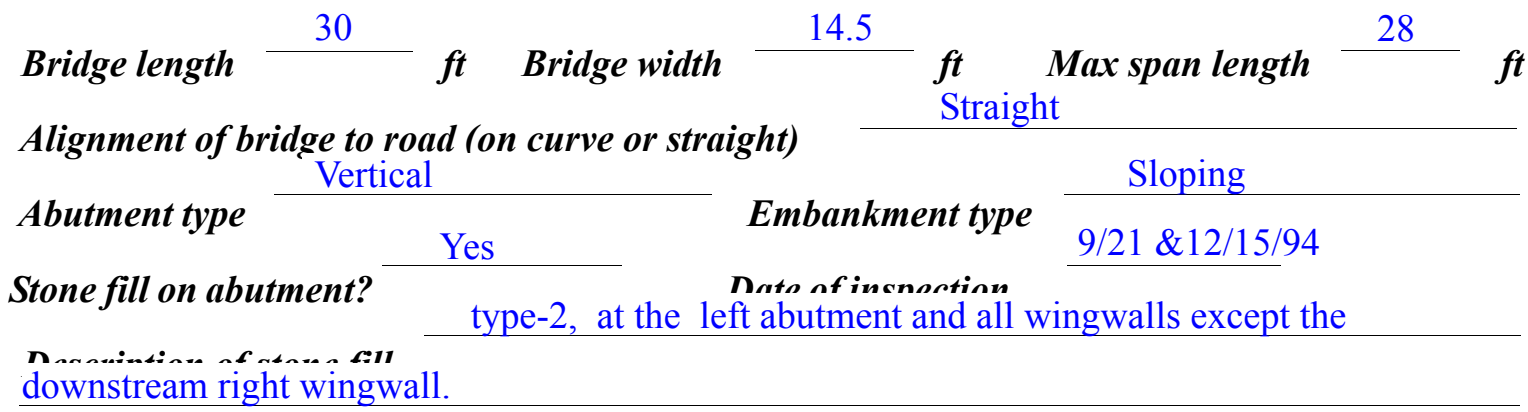

Abutments and wingwalls are concrete. There is a half

foot deep scour hole along the right abutment. The entire right abutment and both wingwall footings are exposed with undermining along the downstream end $0.5 \mathrm{ft}$. deep.

No ' survey?
0

Angle

Debris accumulation on bridge at time of Level I or Level II site visit:

\begin{tabular}{|c|c|c|c|}
\hline & $\begin{array}{l}\text { Date sf incnostion } \\
09 / 21 \& 12 / 15 / 94\end{array}$ & $\begin{array}{l}\text { Porcent of rlommal } \\
\text { vlocked inorizontatly }\end{array}$ & $\begin{array}{l}\text { Percent of } 0 \\
\text { blocked verticatty }\end{array}$ \\
\hline evel I & $09 / 27 / 94$ & -- & -- \\
\hline el II & Low & & \\
\hline
\end{tabular}

\section{Potential for debris}

09/21 \& 12/15/94 -- A gravel, cobble, and boulder side bar from $150 \mathrm{ft}$. upstream along the left Dosrriho anv, fonturos noar ar at tho hridos that mav affort flow, (includo ahsorvation dato) bank to the upstream bridge face. 


\section{Description of the Geomorphic Setting}

General topography The channel is incised with no floodplains and steep valley walls on both sides.

Geomorphic conditions at bridge site: downstream (DS), upstream (US)

Date of inspection $\quad 09 / 21 \& 12 / 15 / 94$

DS left: $\quad$ Steep valley wall

DS right: $\quad$ Steep valley wall with town highway 70 parallel to the creek

US left: $\quad$ Steep valley wall

US right: $\quad$ Steep valley wall with town highway 70 parallel to the creek

\section{Description of the Channel}

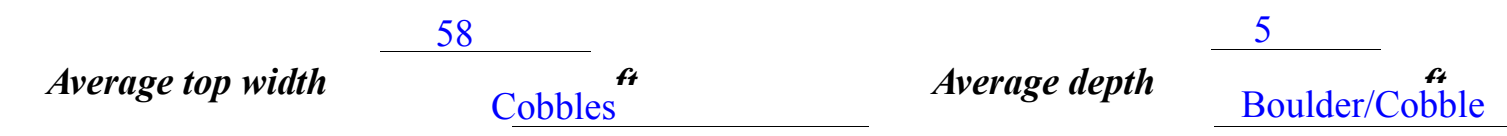

Predominant bed material

Bank material Sinuous but stable with

semi-alluvial channel boundaries and no flood plain.

$9 / 21 \& 12 / 15 / 94$

Vegetative co 1 Forest

DS left: $\quad$ Trees on bank up to town highway 70 with forest beyond

DS right: $\quad$ Forest

US left: $\quad$ Forest with town highway 70 parallel to the stream

US right: $\quad$ Yes

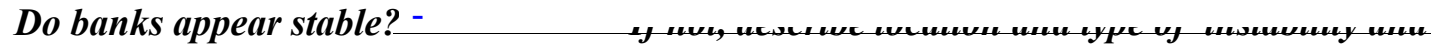

date of observatton.

None

Describe any obstructions in channel and date of observation. 


\title{
Hydrology
}

Drainage area $\quad 24.1 \quad \boldsymbol{m i}^{2}$

Percentage of drainage area in physiographic provinces: (approximate)

Physiographic province

Green Mountain
Percent of drainage area

100

\begin{abstract}
Is drainage area considered rural or urban?
Rural None.

urbanization:-

Describe any significant
\end{abstract}

Is there a USGS gage on the stream of interest?

No

\section{USGS gage description}

USGS gage number

Gage drainage area

$m i^{2}$

No

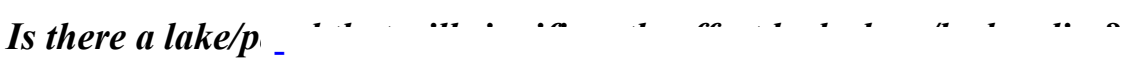

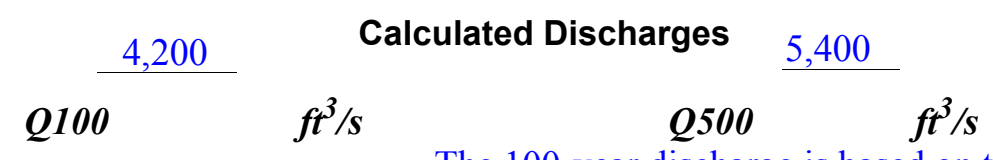

The 100-year discharge is based on the value from

the VTAOT_database (VTAOT, written communication, May 4, 1995) and those computed by use of several empirical methods (Potter, 1957a\&b; Johnson and Tasker, 1974; Benson, 1962; FHWA, 1983; Talbot, 1887; Richardson and others, 1993). The 500-year discharge is based on an extrapolation of the empirical relationship flood frequency curves and that of the VTAOT database values (VTAOT, written communication, May 4, 1995). 


\section{Description of the Water-Surface Profile Model (WSPRO) Analysis}

Datum for WSPRO analysis (USGS survey, sea level, VTAOT plans)

USGS survey

Datum tie between USGS survey and VTAOT plans

Subtract $4,506 \mathrm{ft}$. from USGS

survey to obtain VTAOT plans' datum.

Description of reference marks used to determine USGS datum. $\quad \underline{\mathrm{RM} 1 \text { is a chiseled X in a }}$

chiseled square on top of the US end of the right abutment (elev. $4999.74 \mathrm{ft}$, arbitrary survey

datum). RM2 is a chiseled $\mathrm{X}$ in a chiseled square on top of the DS end of the left abutment

(elev. $4999.92 \mathrm{ft}$, arbitrary survey datum).

\section{Cross-Sections Used in WSPRO Analysis}

\begin{tabular}{|c|c|c|c|}
\hline${ }^{1}$ Cross-section & $\begin{array}{c}\text { Section } \\
\text { Reference } \\
\text { Distance } \\
\text { (SRD) in feet }\end{array}$ & $\begin{array}{c}{ }^{2} \text { Cross-section } \\
\text { development }\end{array}$ & Comments \\
\hline EXIT- & -47 & 1 & Exit section \\
\hline FULLV & 0 & 2 & $\begin{array}{l}\text { Downstream Full-valley } \\
\text { section (Templated from } \\
\text { EXITX) }\end{array}$ \\
\hline BRIDG & 0 & 1 & Bridge section \\
\hline $\mathrm{RD}$ & 10 & 1 & Road Grade section \\
\hline APPR- & 52 & 1 & Approach section \\
\hline
\end{tabular}

${ }^{1}$ For location of cross-sections see plan-view sketch included with Level I field form, Appendix E. For more detail on how cross-sections were developed see WSPRO input file. 


\section{Data and Assumptions Used in WSPRO Model}

Hydraulic analyses of the reach were done by use of the Federal Highway Administration's WSPRO step-backwater computer program (Shearman and others, 1986, and Shearman, 1990). The analysis reported herein reflects conditions existing at the site at the time of the study. Furthermore, in the development of the model it was necessary to assume no accumulation of debris or ice at the site. Results of the hydraulic model are presented in the Bridge Hydraulic Summary, Appendix B, and figure 7.

Channel roughness factors (Manning's " $n$ ") used in the hydraulic model were estimated using field inspections at each cross section following the general guidelines described by Arcement, Jr. and Schneider (1989). Final adjustments to the values were made during the modelling of the reach. Channel " $n$ " values for the reach ranged from 0.042 to 0.058 .

Normal depth at the exit section (EXIT-) was assumed as the starting water surface. This depth was computed by use of the slope-conveyance method outlined in the User's manual for WSPRO (Shearman, 1990). The slope used was $0.0133 \mathrm{ft} / \mathrm{ft}$ which was determined from thalweg points downstream of the bridge.

The approach section (APPR-) was one bridge length upstream of the upstream face as recommended by Shearman and others (1986). This approach also provides a consistent method for determining scour variables.

For the 100-year and incipient road-overflow discharge, WSPRO assumes critical depth at the bridge section. Supercritical models were developed for these discharges. Analyzing both the supercritical and subcritical profiles for each discharge, it can be determined that the water surface profile does pass through critical depth within the bridge opening. Thus, the assumptions of critical depth at the bridge are satifactory solutions.

The incipient road-overflow discharge was determined to be 5,320 cfs. 


\section{Bridge Hydraulics Summary}

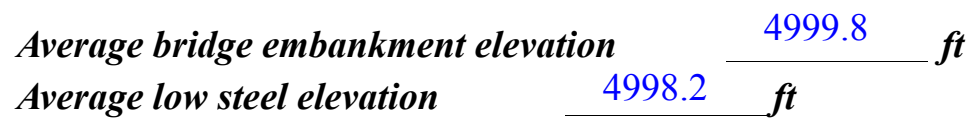

100-year discharge $\quad 4,200 \quad \mathrm{ft}^{3} / \mathrm{s}$

Water-surface elevation in bridge opening $\quad 4991.0 \mathrm{ft}$

Road overtopping? ___ No Discharge over road __ _ , s

Area of flow in bridge opening $\quad 247 \quad \mathrm{ft}^{2}$

Average velocity in bridge opening $17.0 \mathrm{ft} / \mathrm{s}$

Maximum WSPRO tube velocity at bridge $\quad 22.0 \mathrm{ft} / \mathrm{s}$

Water-surface elevation at Approach section with bridge 4996.0

Water-surface elevation at Approach section without bridge $\quad \overline{4992.3}$

Amount of backwater caused by bridge

3.7 it

500-year discharge $\quad 5,400 \quad \mathrm{ft}^{3} / \mathrm{s}$

Water-surface elevation in bridge opening $\quad 4998.3 \boldsymbol{f t}$

Road overtopping? ___ Yes Discharge over road __ $346 \boldsymbol{f t}^{3} / \mathbf{s}$

Area of flow in bridge opening $\quad 440 \quad \mathrm{ft}^{2}$

Average velocity in bridge opening $11.6 \mathrm{ft} / \mathrm{s}$

Maximum WSPRO tube velocity at bridge 14.6 _s

Water-surface elevation at Approach section with bridge 5001.0

Water-surface elevation at Approach section without bridge $\quad 4993.8$

Amount of backwater caused by bridge 7.2 .

Incipient overtopping discharge $\quad 5,320 \mathrm{ft}^{3} / \mathrm{s}$

Water-surface elevation in bridge opening 4992.6 it

Area of flow in bridge opening $\quad 288 \quad \mathbf{f t}^{2}$

Average velocity in bridge opening $\quad 18.5 \quad \mathrm{ft} / \mathrm{s}$

Maximum WSPRO tube velocity at bridge $\quad 24.2 \mathrm{ft} / \mathrm{s}$

Water-surface elevation at Approach section with bridge

Water-surface elevation at Approach section without bridge

Amount of backwater caused by bridge $\quad 4.7$ it

4998.4

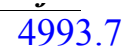




\section{Scour Analysis Summary}

\section{Special Conditions or Assumptions Made in Scour Analysis}

Scour depths were computed using the general guidelines described in Hydraulic Engineering Circular 18 (Richardson and others, 1993). Scour depths were calculated assuming an infinite depth of erosive material and a homogeneous particle-size distribution. The results of the scour analysis are presented in tables 1 and 2 and a graph of the scour depths is presented in figure 8 .

Contraction scour was computed by use of the clear-water contraction scour equation (Richardson and others, 1993, p. 35, equation 18) for the 100-year and incipient road-overflow discharges. Contraction scour was computed by use of the Chang pressure-flow scour equation (Richardson and others, 1995, p. 145-146) for the 500-year discharge, where there was orifice flow at the bridge. Contraction scour at bridges with orifice flow is best estimated by use of the Chang pressure-flow scour equation (oral communication, J. Sterling Jones, October 4, 1996). The results of Laursen's clear-water contraction scour equation (Richardson and others, 1993, p. 35, equation 18) was also computed and can be found in appendix F. For contraction scour computations, the average depth in the contracted section (AREA/TOPWIDTH) is subtracted from the depth of flow computed by the scour equation (Y2) to determine the actual amount of scour. In this case, the incipient road-overflow model resulted in the worst case contraction scour with a scour depth of 3.4 $\mathrm{ft}$. This discharge also resulted in worst case total scour with a depth of $28.5 \mathrm{ft}$. at the left abutment. The results of the streambed armoring computations suggest that the depth of contraction scour will not be limited by armoring.

Abutment scour was computed by use of the Froehlich equation (Richardson and others, 1993, p. 49, equation 24).For the 100-year and incipient overtopping discharge, WSPRO assumes critical depth at the bridge section. Supercritical models were developed for these discharges. Analyzing both the supercritical and subcritical profiles for each discharge, it can be determined that the water surface profile does pass through critical depth within the bridge opening. Thus, the assumptions of critical depth at the bridge are satifactory solutions.

Variables for the Froehlich equation include the Froude number of the flow approaching the embankments, the length of the embankment blocking flow, and the depth of flow approaching the embankment less any roadway overtopping. 


\section{Scour Results}

$$
\text { 100-yr discharge 500-yr discharge }
$$

Contraction scour:

(Scour depths in feet)

Main channel

Live-bed scour

Clear-water scour

Depth to armoring

Left overbank

Right overbank

Local scour:

Abutment scour

Left abutment

Right abutment

Pier scour

Pier 1

Pier 2

Pier 3
21.7

11.5
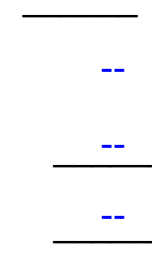

Incipient overtopping discharge

(Scour depths infeet)

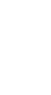




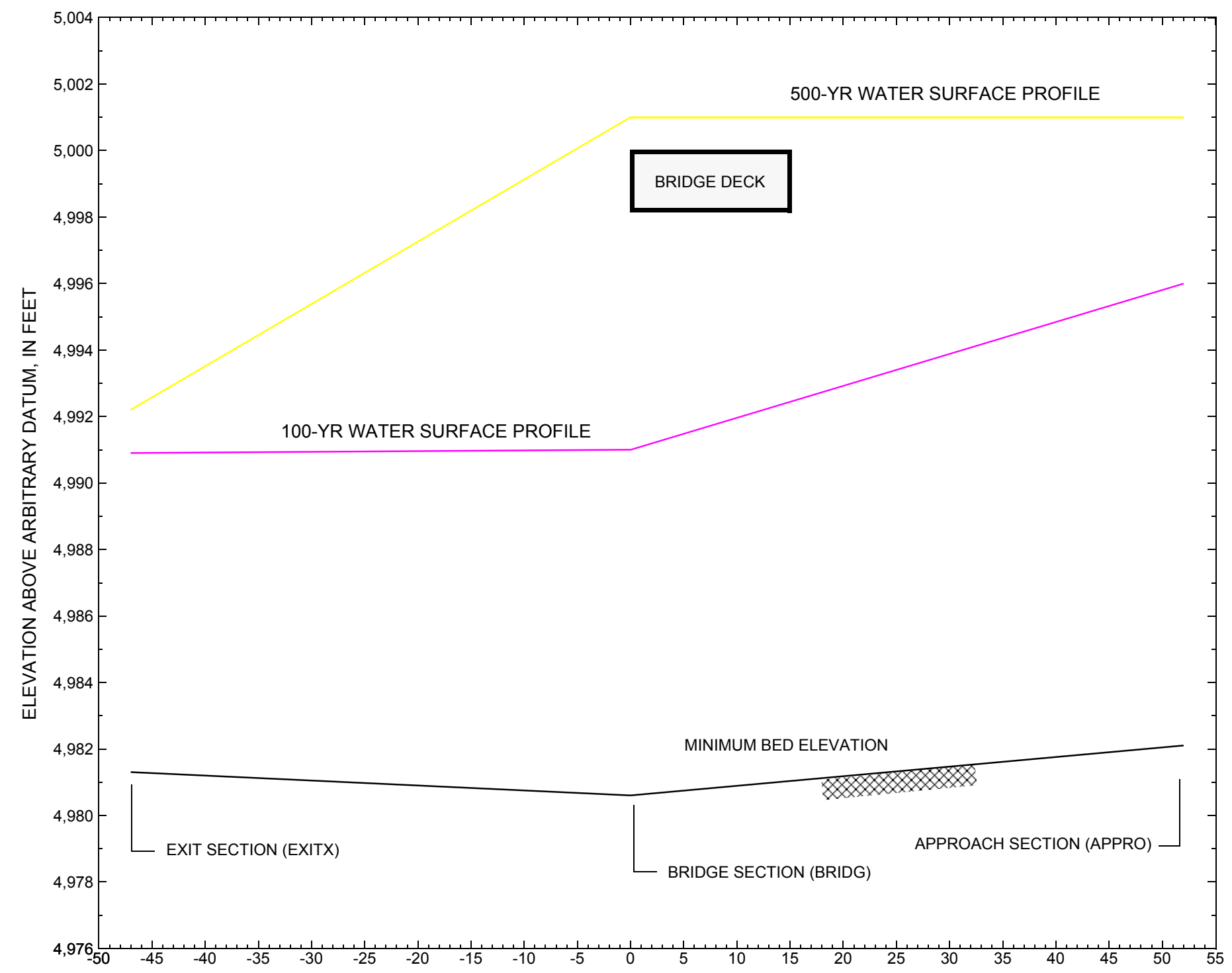

Figure 7. Water-surface profiles for the 100- and 500-yr discharges at structure BRNATH00680035 on town highway 68, crossing Locust Creek, Barnard, Vermont. 


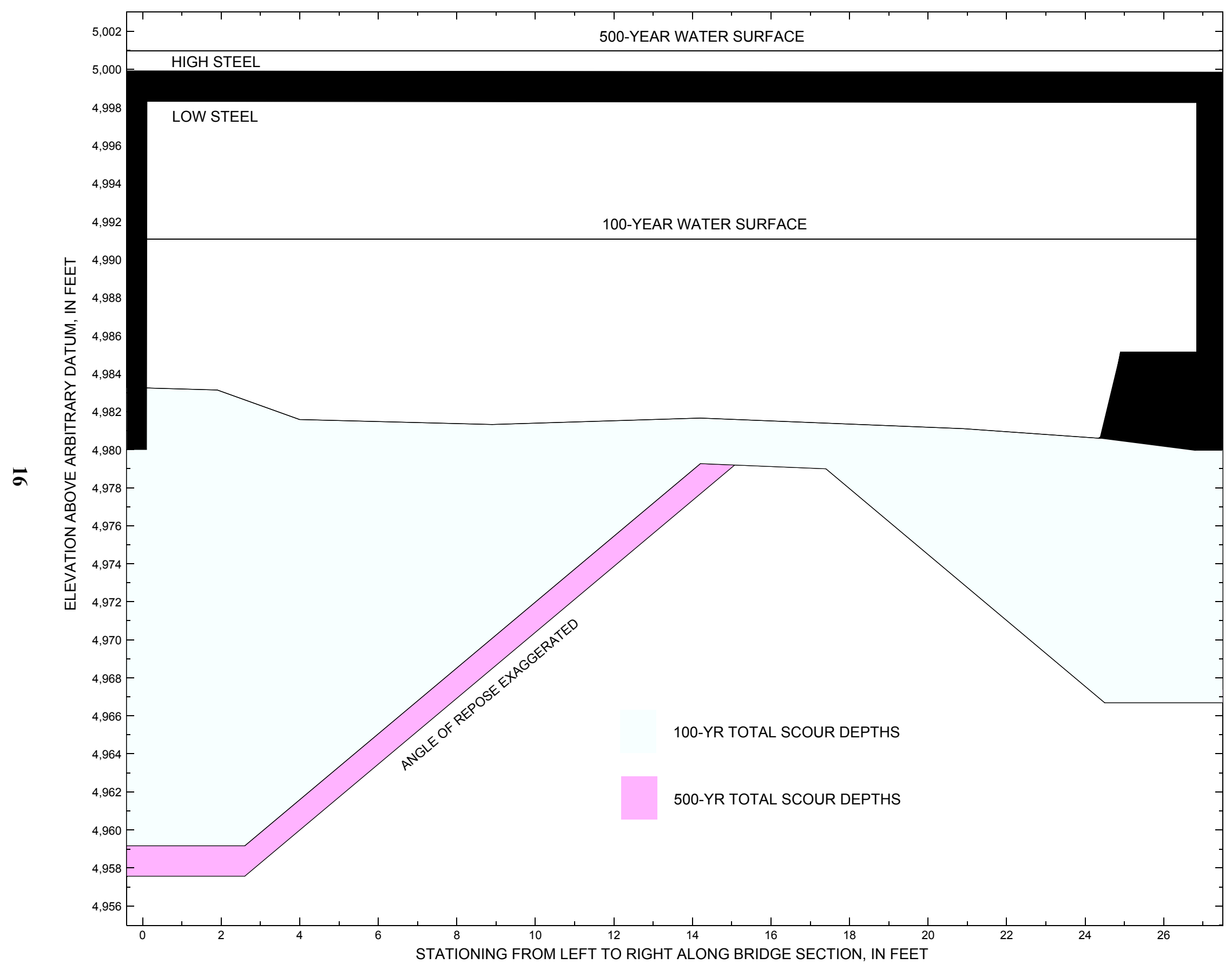

Figure 8. Scour elevations for the 100-yr and 500-yr discharges at structure BRNATH00680035 on town highway 68, crossing Locust Creek, Barnard, Vermont. 
Table 1. Remaining footing/pile depth at abutments for the 100-year discharge at structure BRNATH00680035 on Town Highway 68, crossing Locust Creek, Barnard, Vermont.

[VTAOT, Vermont Agency of Transportation; --,no data]

\begin{tabular}{|c|c|c|c|c|c|c|c|c|c|c|c|}
\hline Description & Station $^{1}$ & $\begin{array}{c}\text { VTAOT } \\
\text { plans' } \\
\text { bridge seat } \\
\text { elevation } \\
\text { (feet) }\end{array}$ & $\begin{array}{l}\text { Surveyed } \\
\text { minimum } \\
\text { low-chord } \\
\text { elevation } \\
\quad \text { (feet) }\end{array}$ & $\begin{array}{l}\text { Bottom of } \\
\text { footing } \\
\text { elevation } \\
\text { (feet) }\end{array}$ & $\begin{array}{c}\text { Channel } \\
\text { elevation at } \\
\text { abutment/ } \\
\text { pier }^{2} \\
\text { (feet) }\end{array}$ & $\begin{array}{l}\text { Contraction } \\
\text { scour depth } \\
\text { (feet) }\end{array}$ & $\begin{array}{l}\text { Abutment } \\
\text { scour } \\
\text { depth } \\
\text { (feet) }\end{array}$ & $\begin{array}{l}\text { Pier } \\
\text { scour } \\
\text { depth } \\
\text { (feet) }\end{array}$ & $\begin{array}{l}\text { Depth of } \\
\text { total scour } \\
\text { (feet) }\end{array}$ & $\begin{array}{c}\text { Elevation of } \\
\text { scour }^{2} \\
\text { (feet) }\end{array}$ & $\begin{array}{c}\text { Remaining } \\
\text { footing/pile } \\
\text { depth } \\
\text { (feet) }\end{array}$ \\
\hline \multicolumn{12}{|c|}{100 -yr. discharge is 4,200 cubic-feet per second } \\
\hline Left abutment & 0.0 & 492.1 & 4998.3 & 4980 & 4983.3 & 2.4 & 21.7 & -- & 24.1 & 4959.2 & -21 \\
\hline Right abutment & 27.0 & 492.8 & 4998.1 & 4980 & 4980.6 & 2.4 & 11.5 & -- & 13.9 & 4966.7 & -13 \\
\hline
\end{tabular}

1. Measured along the face of the most constricting side of the bridge.

2. Arbitrary datum for this study.

Table 2. Remaining footing/pile depth at abutments for the 500-year discharge at structure BRNATH00680035 on Town Highway 68, crossing Locust Creek, Barnard, Vermont.

[VTAOT, Vermont Agency of Transportation; --, no data]

\begin{tabular}{|c|c|c|c|c|c|c|c|c|c|c|c|}
\hline Description & Station $^{1}$ & $\begin{array}{c}\text { VTAOT } \\
\text { plans' } \\
\text { bridge seat } \\
\text { elevation } \\
\text { (feet) }\end{array}$ & $\begin{array}{l}\text { Surveyed } \\
\text { minimum } \\
\text { low-chord } \\
\text { elevation } \\
\quad \text { (feet) }\end{array}$ & $\begin{array}{l}\text { Bottom of } \\
\text { footing } \\
\text { elevation } \\
\text { (feet) }\end{array}$ & $\begin{array}{c}\text { Channel } \\
\text { elevation at } \\
\text { abutment/ } \\
\text { pier }^{2} \\
\text { (feet) }\end{array}$ & $\begin{array}{l}\text { Contraction } \\
\text { scour depth } \\
\text { (feet) }\end{array}$ & $\begin{array}{l}\text { Abutment } \\
\text { scour } \\
\text { depth } \\
\text { (feet) }\end{array}$ & $\begin{array}{l}\text { Pier } \\
\text { scour } \\
\text { depth } \\
\text { (feet) }\end{array}$ & $\begin{array}{l}\text { Depth of } \\
\text { total scour } \\
\text { (feet) }\end{array}$ & $\begin{array}{c}\text { Elevation of } \\
\text { scour }^{2} \\
\text { (feet) }\end{array}$ & $\begin{array}{c}\text { Remaining } \\
\text { footing/pile } \\
\text { depth } \\
\text { (feet) }\end{array}$ \\
\hline \multicolumn{12}{|c|}{ 500-yr. discharge is 5,400 cubic-feet per second } \\
\hline Left abutment & 0.0 & 492.1 & 4998.3 & 4980 & 4983.3 & 0 & 25.7 & -- & 25.7 & 4957.6 & -22 \\
\hline Right abutment & 27.0 & 492.8 & 4998.1 & 4980 & 4980.6 & 0 & 13.2 & -- & 13.2 & 4967.4 & -13 \\
\hline
\end{tabular}

1. Measured along the face of the most constricting side of the bridge.

2. Arbitrary datum for this study. 


\section{SELECTED REFERENCES}

Arcement, G.J., Jr., and Schneider, V.R., 1989, Guide for selecting Manning's roughness coefficients for natural channels and flood plains: U.S. Geological Survey Water-Supply Paper 2339, 38 p.

Barnes, H.H., Jr., 1967, Roughness characteristics of natural channels: U.S. Geological Survey Water-Supply Paper 1849, 213 p.

Benson, M.A., 1962, Factors influencing the occurrence of floods in a humid region of diverse terrain: U.S. Geological Survey Water-Supply Paper 1580-B, 64 p.

Brown, S.A. and Clyde, E.S., 1989, Design of riprap revetment: Federal Highway Administration Hydraulic Engineering Circular No. 11, Publication FHWA-IP-89-016, 156 p.

Federal Highway Administration, 1983, Runoff estimates for small watersheds and development of sound design: Federal Highway Administration Report FHWA-RD-77-158

Froehlich, D.C., 1989, Local scour at bridge abutments in Ports, M.A., ed., Hydraulic Engineering--Proceedings of the 1989 National Conference on Hydraulic Engineering: New York, American Society of Civil Engineers, p. 13-18.

Hayes, D.C.,1993, Site selection and collection of bridge-scour data in Delaware, Maryland, and Virginia: U.S. Geological Survey WaterResources Investigation Report 93-4017, 23 p.

Johnson, C.G. and Tasker, G.D.,1974, Progress report on flood magnitude and frequency of Vermont streams: U.S. Geological Survey Open-File Report 74-130, 37 p.

Lagasse, P.F., Schall, J.D., Johnson, F., Richardson, E.V., Richardson, J.R., Chang, F., 1991, Stream Stability at Highway Structures: Federal Highway Administration Hydraulic Engineering Circular No. 20, Publication FHWA-IP-90-014, 195 p.

Laursen, E.M., 1960, Scour at bridge crossings: Journal of the Hydraulics Division, American Society of Civil Engineers, v. 86, no. HY2, p. $39-53$.

Potter, W. D., 1957a, Peak rates of runoff in the Adirondack, White Mountains, and Maine woods area, Bureau of Public Roads

Potter, W. D., 1957b, Peak rates of runoff in the New England Hill and Lowland area, Bureau of Public Roads

Richardson, E.V., and Davis, S.R., 1995, Evaluating scour at bridges: Federal Highway Administration Hydraulic Engineering Circular No. 18, Publication FHWA-IP-90-017, 204 p.

Richardson, E.V., Harrison, L.J., Richardson, J.R., and Davis, S.R., 1993, Evaluating scour at bridges: Federal Highway Administration Hydraulic Engineering Circular No. 18, Publication FHWA-IP-90-017, 131 p.

Richardson, E.V., Simons, D.B., and Julien, P.Y., 1990, Highways in the river environment: Federal Highway Administration Publication FHWA-HI-90-016.

Ritter, D.F., 1984, Process Geomorphology: W.C. Brown Co., Debuque, Iowa, 603 p.

Shearman, J.O., 1990, User's manual for WSPRO--a computer model for water surface profile computations: Federal Highway Administration Publication FHWA-IP-89-027, 187 p.

Shearman, J.O., Kirby, W.H., Schneider, V.R., and Flippo, H.N., 1986, Bridge waterways analysis model; research report: Federal Highway Administration Publication FHWA-RD-86-108, 112 p.

Talbot, A.N., 1887, The determination of water-way for bridges and culverts.

U.S. Department of Transportation, 1993, Stream stability and scour at highway bridges, Participant Workbook: Federal Highway Administration Publication FHWA HI-91-011.

U.S. Geological Survey, 1980, Bethel, Vermont 7.5 Minute Series quadrangle map: U.S. Geological Survey Topographic Maps, Scale 1:24,000. 


\section{APPENDIX A: \\ WSPRO INPUT FILE}




\section{WSPRO INPUT FILE}

GR

GR

N

* $\mathrm{X}$

BR

GR

GR

GR

GR

$\mathrm{N}$

CD

*

$\mathrm{XR}$

GR

GR

GR

BP

AS

GR

GR

GR

GR

N

*

HP 1 BRDG-

HP 2 BRDG-

$\mathrm{HP} 1 \mathrm{APPR}-$

$\mathrm{HP} 2 \mathrm{APPR}-$

*

HP 1 BRDG -

HP 2 BRDG-

HP 2 RD

HP 1 APPR -

$\mathrm{HP} 2 \mathrm{APPR}-$

*

HP 1 BRDGHP 2 BRDG $\mathrm{HP} 1 \mathrm{APPR}-$

U.S. GEOLOGICAL SURVEY WSPRO INPUT FILE brna035.wsp CREATED ON 06-NOV-95 FOR BRIDGE brnath00680035 USING FILE brna035.dca Hydraulic analysis of barnard035 ts

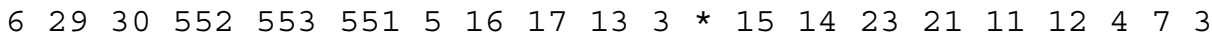

$4200.0, \quad 5400.0, \quad 5320.0$

$0.0133 \quad 0.0133 \quad 0.0133$

EXIT- $\quad-47$

$$
-41.7,5006.22
$$

$-17.6,4988.91$

$0.0,4982.59$

$-3.3,4981.87$

$27.2,4982.87$

$22.4,4981.21$

$43.2,4995.67$

0.058

$59.1,4997.02$

$-12.3,4984.85$

$4.7,4982.06$

$27.2,4982.88$

$70.1,4996.23$

0.0062

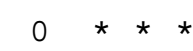

$$
0
$$

4998.2

$0.0,4998.33$

$8.9,4981.32$

$24.7,4983.00$

$0.0,4998.33$

$$
0.042
$$

1

$31.3 * *$

0.0

$$
0.1,4983.27
$$

$14.2,4981.66$

$24.9,4985.13$

50

9.5

$$
\begin{array}{crr}
10 & 14.5 & 2 \\
-35.4,5001.74 & -17 \\
28.0,4999.81 & 52 \\
85.9,5009.16 & \\
0 &
\end{array}
$$$$
-17.7,5000.41
$$$$
52.6,5000.32
$$

$-5.3,4982.56$

$16.3,4981.33$

$32.5,4987.02$

$78.5,5006.05$

52

$-70.9,5009.47$

$0.0,4983.79$

$24.6,4983.80$

$36.5,4993.11$

0.058

$\begin{array}{rrr}-43.9,4995.04 & -32.6,4992.66 & -20.6,4987.38 \\ 9.4,4982.74 & 16.1,4982.06 & 21.6,4982.12 \\ 24.6,4983.79 & 27.1,4986.94 & 32.9,4990.34 \\ 42.4,4997.70 & 53.1,5003.67 & 57.9,5004.37\end{array}$

$57.9,5004.37$
$0.0,4999.95$

$13.6,4999.72$

$63.5,5000.97$

$73.8,5000.09$

$20.9,4981.10$

$26.8,4985.13$

$24.4,4980.59$

$27.0,4998.14$ 


\section{APPENDIX B: \\ WSPRO OUTPUT FILE}


WSPRO OUTPUT FILE

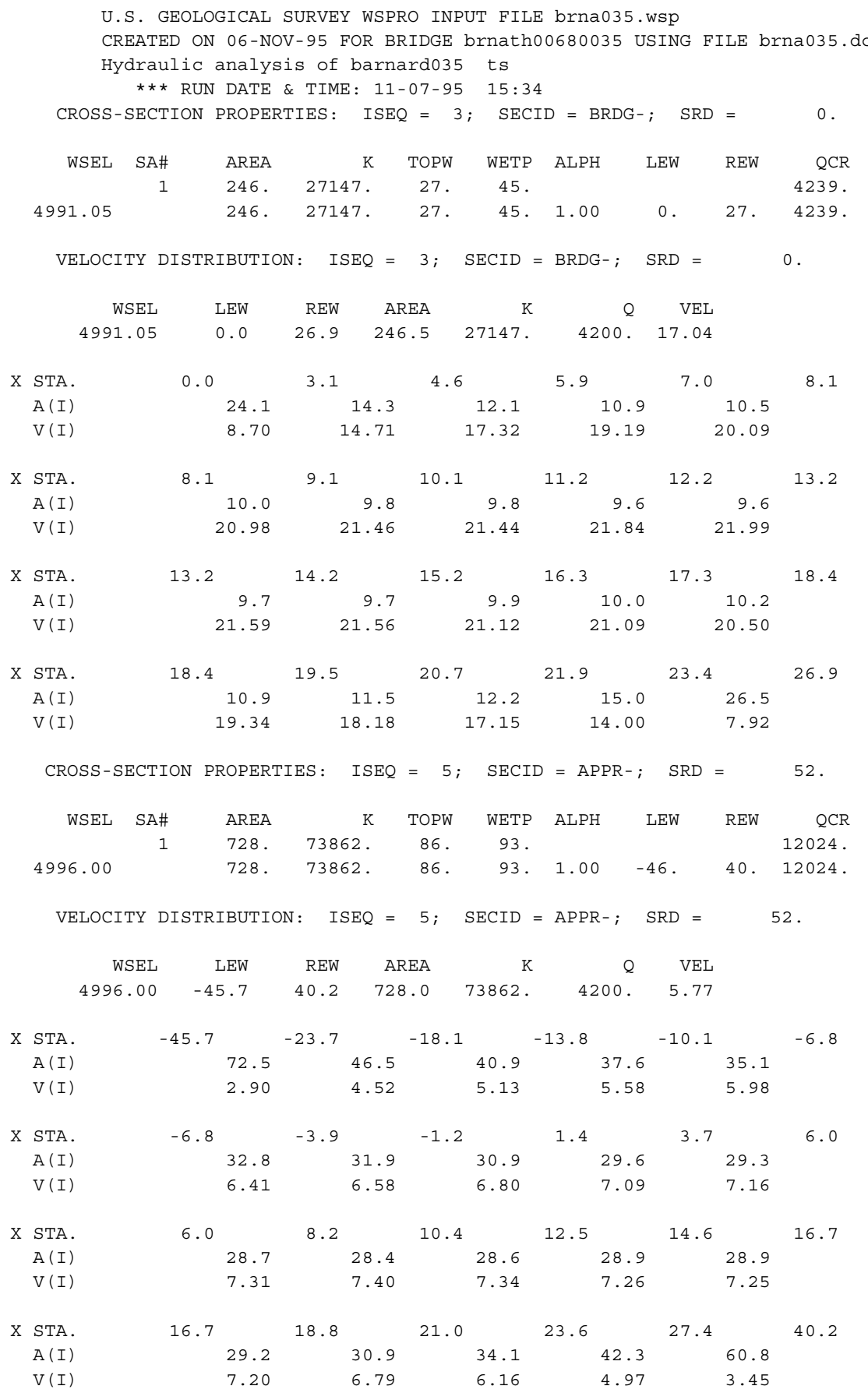


WSPRO OUTPUT FILE (continued)

\begin{tabular}{|c|c|c|c|c|c|c|c|c|c|c|c|}
\hline & CROSS-SEC & CTION & PROPERT & TIES : & ISEQ & $2=$ & SEC & $\operatorname{CID}=\mathrm{BRDG}$ & SRD & $=$ & 0 . \\
\hline & WSEL SA & A\# & AREA & & $\mathrm{K}$ & TOPW & WETP & ALPH & LEW & REW & QCR \\
\hline & & 1 & 440 & 4618 & 81. & 0 . & 86. & & & & 0 . \\
\hline & 4998.33 & & 440. & 4618 & & 0 . & 86. & 1.00 & 0. & 27 . & 0 . \\
\hline & VELOCITY & DISTI & RIBUTIOI & $\mathrm{N}$ : & $\mathrm{SEQ}=$ & $3 ;$ & SECID & $=$ BRDG $-;$ & $\mathrm{SRD}=$ & & 0 . \\
\hline & WSEL & & LEW & REW & AREZ & & $\mathrm{K}$ & $\mathrm{Q}$ & VEL & & \\
\hline & 4998.33 & & 0.0 & 27.0 & 439 & 9.9 & 46181. & 5097. & 11.59 & & \\
\hline $\mathrm{X}$ & STA. & 0. & & 2.9 & & 4.4 & & 5.7 & 6.9 & & 8.0 \\
\hline & $A(I)$ & & 42.8 & & 25.4 & & 21.5 & 20. & & 19.0 & \\
\hline & $V(I)$ & & 5.95 & & 10.02 & & 11.83 & 12.7 & & 13.39 & \\
\hline $\mathrm{x}$ & STA. & 8. & & 9.1 & & 10.1 & & 11.2 & 12.2 & & 13.3 \\
\hline & $A(I)$ & & 18.2 & & 18.1 & & 17.8 & 17. & & 17.4 & \\
\hline & $V(I)$ & & 14.02 & & 14.10 & & 14.35 & 14.5 & & 14.65 & \\
\hline $\mathrm{x}$ & STA. & 13. & & 14.3 & & 15.4 & & 16.5 & 17.5 & & 18.7 \\
\hline & $A(I)$ & & 17.6 & & 17.6 & & 17.9 & 17. & & 18.7 & \\
\hline & $V(I)$ & & 14.49 & & 14.47 & & 14.23 & 14.2 & & 13.60 & \\
\hline $\mathrm{x}$ & STA. & 18. & & 19.8 & & 21.0 & & 22.3 & 23.7 & & 27.0 \\
\hline & $A(I)$ & & 18.9 & & 20.4 & & 22.3 & 25 . & & 45.5 & \\
\hline & $V(I)$ & & 13.50 & & 12.47 & & 11.43 & 9.9 & & 5.61 & \\
\hline & VELOCITY & DISTI & RIBUTIOI & $\mathrm{N}:$ IS & $\mathrm{SEQ}=$ & $4 ;$ & SECID $=$ & $=\mathrm{RD}$ & $\mathrm{SRD}=$ & & 10. \\
\hline & WSEL & & LEW & REW & ARI & $\mathrm{EA}$ & K & Q & VEL & & \\
\hline & 5001.02 & 2 & 25.8 & 75.0 & 84 & .7 & 1933. & 346 . & 4.08 & & \\
\hline $\mathrm{x}$ & STA. & -25. & & -12.0 & & -6.3 & & -1.9 & 1.8 & & 5.1 \\
\hline & $A(I)$ & & 6.4 & & 4.7 & & 4.2 & 3. & .9 & 3.7 & \\
\hline & $V(I)$ & & 2.70 & & 3.65 & & 4.13 & 4.4 & & 4.64 & \\
\hline $\mathrm{x}$ & STA. & 5. & & 8.1 & & 11.0 & & 13.7 & 16.3 & & 19.0 \\
\hline & $A(I)$ & & 3.6 & & 3.5 & & 3.5 & 3. & .4 & 3.5 & \\
\hline & $V(I)$ & & 4.79 & & 4.91 & & 5.00 & 5.0 & & 5.00 & \\
\hline $\mathrm{x}$ & STA. & 19. & & 21.8 & & 24.7 & & 27.6 & 30.8 & & 34.2 \\
\hline & $A(I)$ & & 3.5 & & 3.5 & & 3.6 & 3. & .7 & 3.8 & \\
\hline & $V(I)$ & & 4.97 & & 4.89 & & 4.81 & 4.6 & & 4.51 & \\
\hline $\mathrm{x}$ & STA. & 34.2 & & 38.1 & & 42.7 & & 48.4 & 56.7 & & 75.0 \\
\hline & $A(I)$ & & 4.0 & & 4.4 & & 4.9 & 5. & .4 & 7.4 & \\
\hline & $V(I)$ & & 4.30 & & 3.93 & & 3.56 & 3.1 & & 2.35 & \\
\hline & CROSS-SEC & CTION & PROPERT & TIES : & ISEQ & $=5$ & SEC & $I D=A P P R$ & SRD & $=$ & 52. \\
\hline & WSEL SA & $\mathrm{AA \#}$ & AREA & & $\mathrm{K}$ & TOPW & WETP & ALPH & LEW & REW & QCR \\
\hline & & 1 & 1202. & 14933 & 34. & 103. & 113. & & & & 23245 . \\
\hline & 5001.02 & & 1202. & 14933 & 34. & 103. & 113. & 1.00 & -55 & 48. & 23245 . \\
\hline & VELOCITY & DISTR & RIBUTION & $\mathrm{N}:$ IS & $\mathrm{SEQ}=$ & $5 ;$ & SECID $=$ & $=\mathrm{APPR}-;$ & $\mathrm{SRD}=$ & & 52. \\
\hline & WSEL & & LEW & REW & ARE & & K & $Q$ & VEL & & \\
\hline & 5001.02 & & 55.1 & 48.4 & 1201 & .8 & 49334. & 5400 . & 4.49 & & \\
\hline $\mathrm{x}$ & STA. & -55.1 & & -33.2 & & -25.2 & & -20.1 & -15.8 & & -12.0 \\
\hline & $A(I)$ & & 109.7 & & 78.9 & & 65.3 & 60. & & 55.3 & \\
\hline & $V(I)$ & & 2.46 & & 3.42 & & 4.13 & 4.4 & & 4.89 & \\
\hline $\mathrm{x}$ & STA. & -12. & & -8.5 & & -5.3 & & -2.3 & 0.6 & & 3.3 \\
\hline & $A(I)$ & & 53.8 & & 52.1 & & 50.3 & 49. & & 47.4 & \\
\hline & $V(I)$ & & 5.02 & & 5.18 & & 5.36 & 5.4 & & 5.70 & \\
\hline $\mathrm{x}$ & STA. & 3.3 & & 6.0 & & 8.7 & & 11.3 & 13.8 & & 16.4 \\
\hline & $A(I)$ & & 47.1 & & 47.9 & & 47.5 & 47. & & 48.9 & \\
\hline & $V(I)$ & & 5.73 & & 5.63 & & 5.68 & 5.7 & & 5.52 & \\
\hline $\mathrm{X}$ & STA. & 16.4 & & 19.0 & & 21.8 & & 25.1 & 30.4 & & 48.4 \\
\hline & $A(I)$ & & 49.8 & & 53.2 & & 59.1 & 73. & & 104.8 & \\
\hline & $\mathrm{V}(\mathrm{I})$ & & 5.42 & & 5.08 & & 4.56 & 3.6 & & 2.58 & \\
\hline
\end{tabular}


WSPRO OUTPUT FILE (continued)

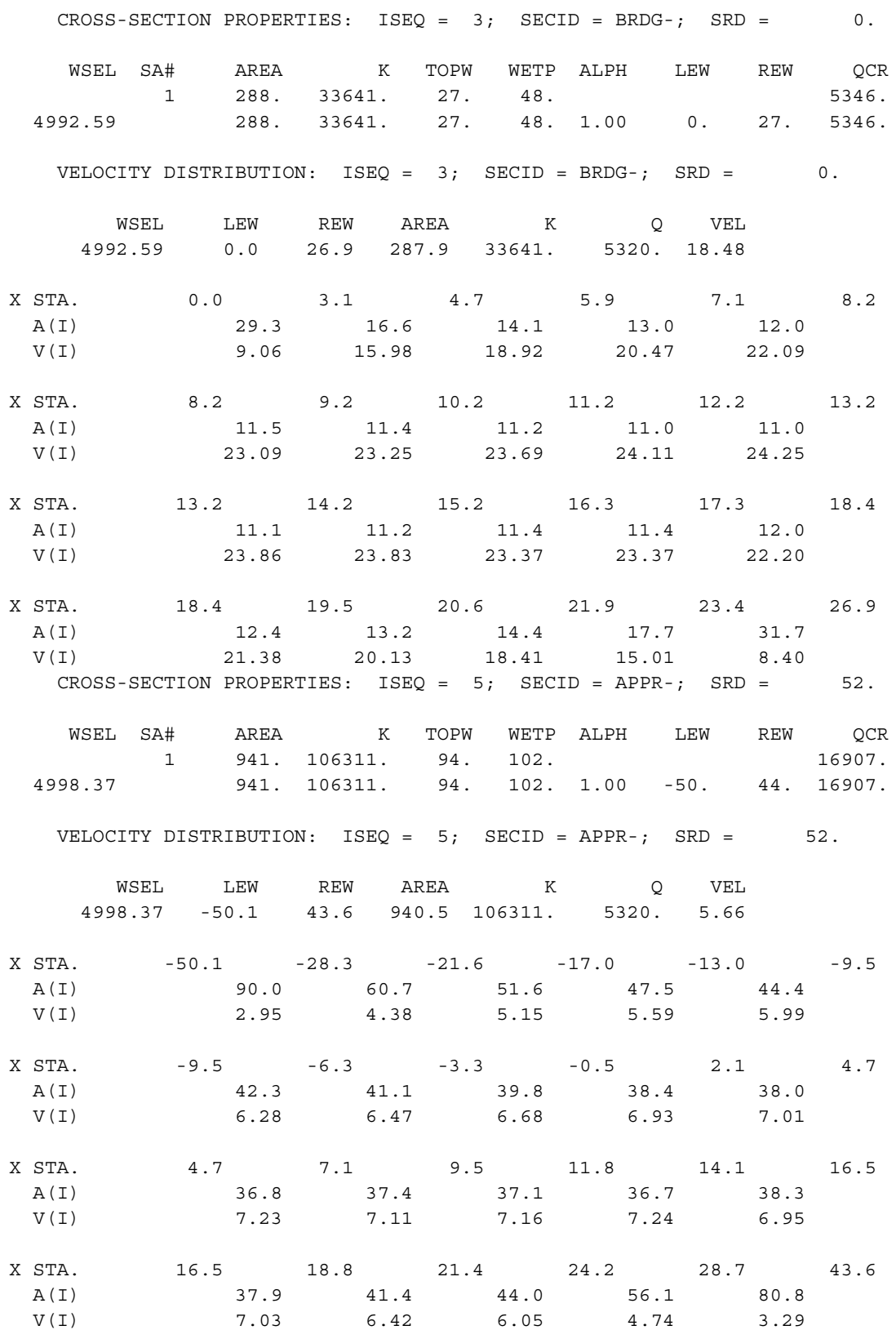


WSPRO OUTPUT FILE (continued)

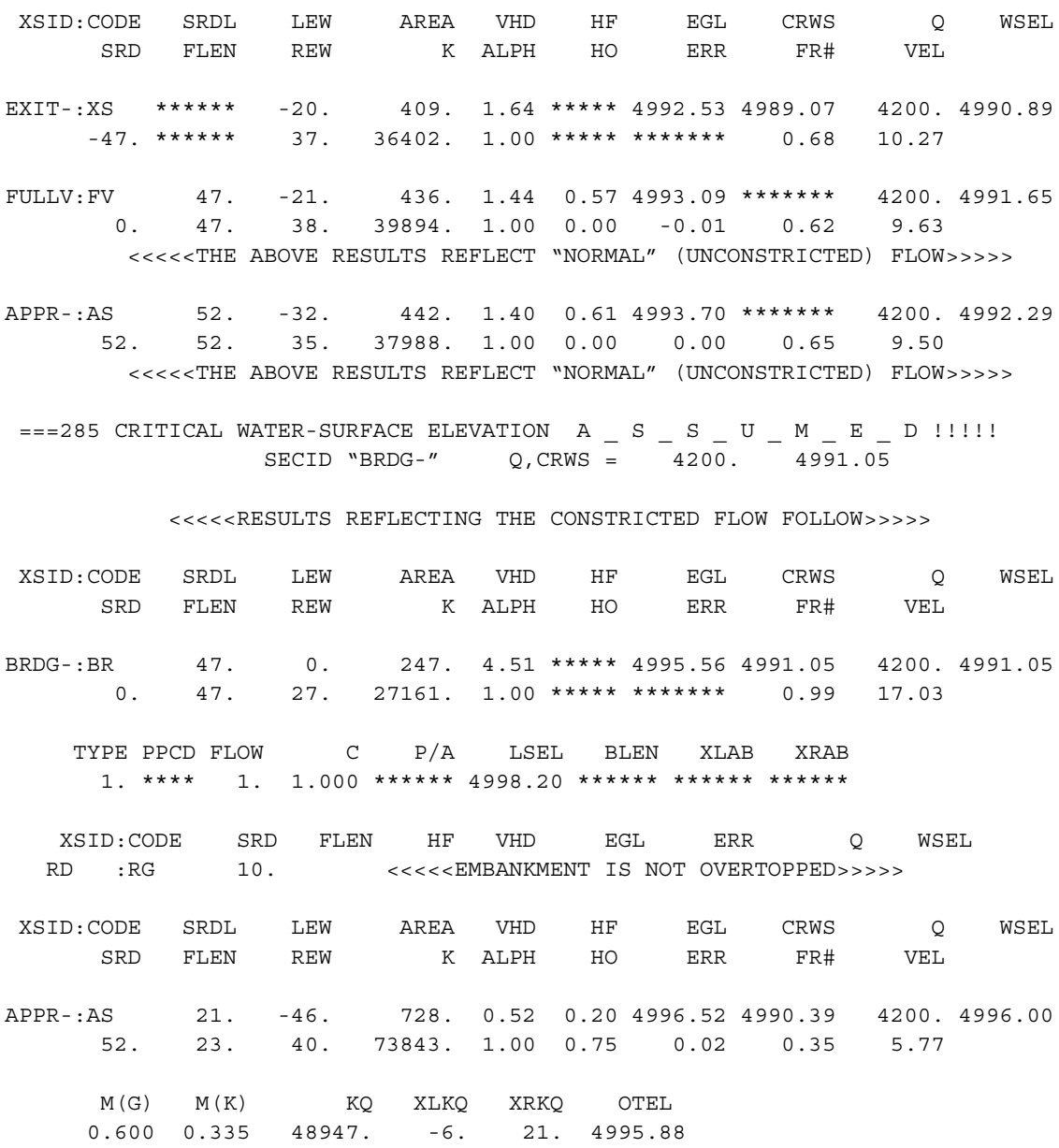

FIRST USER DEFINED TABLE.

\begin{tabular}{|c|c|c|c|c|c|c|c|c|}
\hline XSID : CODE & SRD & LEW & REW & Q & $\mathrm{K}$ & AREA & VEL & WSEL \\
\hline EXIT-:XS & -47 & -20 & 37. & 4200 . & 36402 . & 409 & 10.27 & 4990.89 \\
\hline FULLV : FV & 0 . & -21 & 38. & 4200 . & 39894 . & 436 & 9.63 & 4991.65 \\
\hline BRDG- : BR & 0 & 0 & 27. & 4200 . & 27161 & 247 & 17.03 & 4991.05 \\
\hline$:$ RG & \multicolumn{3}{|c|}{$10 . * * \star * \star * \star * \star * * * \star * * *$} & \multicolumn{3}{|c|}{ 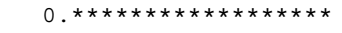 } & \multicolumn{2}{|c|}{ 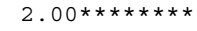 } \\
\hline APPR-: AS & 52. & -46 & 40 & 4200. & 73843 & 728 & 5.77 & 4996.00 \\
\hline XSID : CODE & XLKQ & XRKQ & & & & & & \\
\hline$A P P R-: A S$ & 6 . & 1 . & & & & & & \\
\hline
\end{tabular}

SECOND USER DEFINED TABLE.

\begin{tabular}{|c|c|c|c|c|c|c|c|c|c|}
\hline XSID : CODE & CRWS & FR\# & YMIN & YMAX & $\mathrm{HF}$ & $\mathrm{HO}$ & VHD & EGL & WSEL \\
\hline EXIT-:XS & 4989.07 & 0.68 & 4981.21 & $5006.22 *$ & $\star * \star * \star * \star *$ & $\star \star \star \star * *$ & 1.64 & 4992.53 & 4990.89 \\
\hline FULLV : FV & 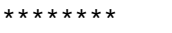 & 0.62 & 4981.50 & 5006.51 & 0.57 & 0.00 & 1.44 & 4993.09 & 4991.65 \\
\hline BRDG- : BR & 4991.05 & 0.99 & 4980.59 & $4998.33 *$ & $\star \star \star \star * \star$ & $\star \star \star \star \star *$ & 4.51 & 4995.56 & 4991.05 \\
\hline : RG & 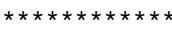 & $* * * *$ & 4999.72 & $5009.16 *$ & $\star \star \star * \star *$ & $\star \star \star \star *$ & $\star \star \star * *$ & $\star \star \star \star \star \star *$. & $\star \star \star \star \star \star *$ \\
\hline APPR-:AS & 4990.39 & 0.35 & 4982.06 & 5009.47 & 0.20 & 0.75 & 0.52 & 4996.52 & 4996.00 \\
\hline
\end{tabular}


WSPRO OUTPUT FILE (continued)

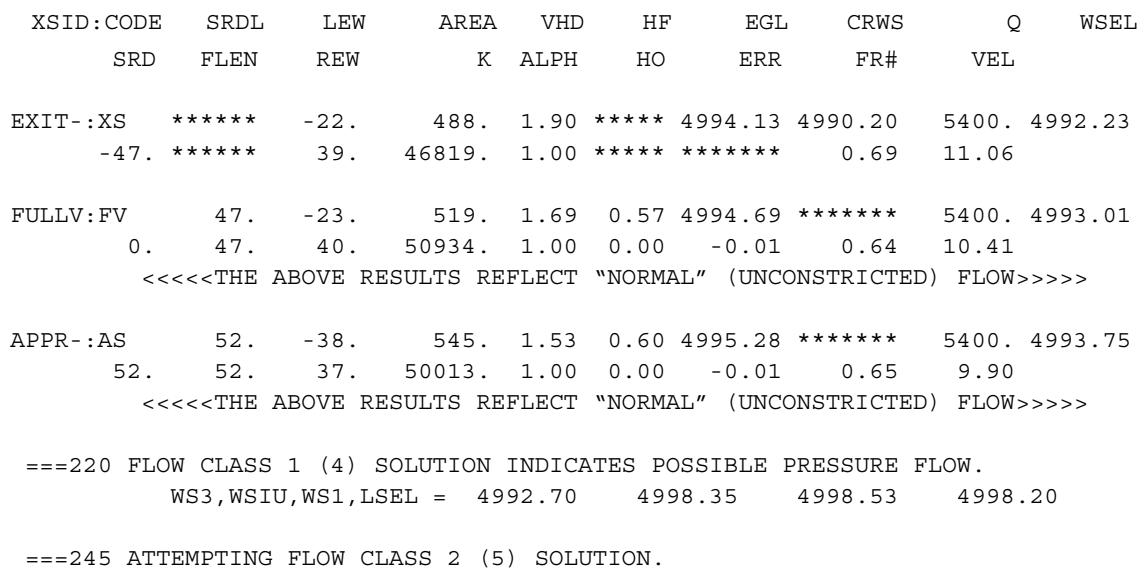

FIRST USER DEFINED TABLE.

\begin{tabular}{|c|c|c|c|c|c|c|c|c|}
\hline XSID : CODE & SRD & LEW & REW & $Q$ & K & AREA & VEL & WSEL \\
\hline EXIT-:XS & -47 & -22 . & 39. & 5400 . & 46819 . & 488 . & 11.06 & 4992.23 \\
\hline FULLV : FV & 0 & -23. & 40. & 5400 . & 50934 . & 519. & 10.41 & 4993.01 \\
\hline BRDG- : BR & 0 . & 0 . & 27. & 5097. & 46181. & 440 & 11.59 & 4998.33 \\
\hline$:$ RG & 10 * * & $* * * *$ & 134. & 346. & $* \star * * * *$ & 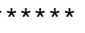 & 2.00 & 5001.02 \\
\hline APPR-:AS & 52. & -55 & 48. & 5400 . & 149290. & 1202 . & 4.49 & 5001.02 \\
\hline
\end{tabular}

SECOND USER DEFINED TABLE.

$\begin{array}{lcrrrrrrrr}\text { XSID : CODE } & \text { CRWS } & \text { FR\# } & \text { YMIN } & \text { YMAX } & \text { HF } & \text { HO } & \text { VHD } & \text { EGL } & \text { WSEL } \\ \text { EXIT-:XS } & 4990.20 & 0.69 & 4981.21 & 5006.22 * * * * * * * * * * * & 1.90 & 4994.13 & 4992.23 \\ \text { FULLV:FV } & * * * * * * * * & 0.64 & 4981.50 & 5006.51 & 0.57 & 0.00 & 1.69 & 4994.69 & 4993.01 \\ \text { BRDG-:BR } & 4992.30 & 0.51 & 4980.59 & 4998.33 * * * * * * * * * * * & 2.09 & 5000.42 & 4998.33 \\ \text { RD : RG } & * * * * * * * * * * * * * * * * & 4999.72 & 5009.16 & 0.05 * * * * * * & 0.31 & 5001.28 & 5001.02 \\ \text { APPR-:AS } & 4991.48 & 0.23 & 4982.06 & 5009.47 & 0.09 & 0.78 & 0.31 & 5001.33 & 5001.02\end{array}$


WSPRO OUTPUT FILE (continued)

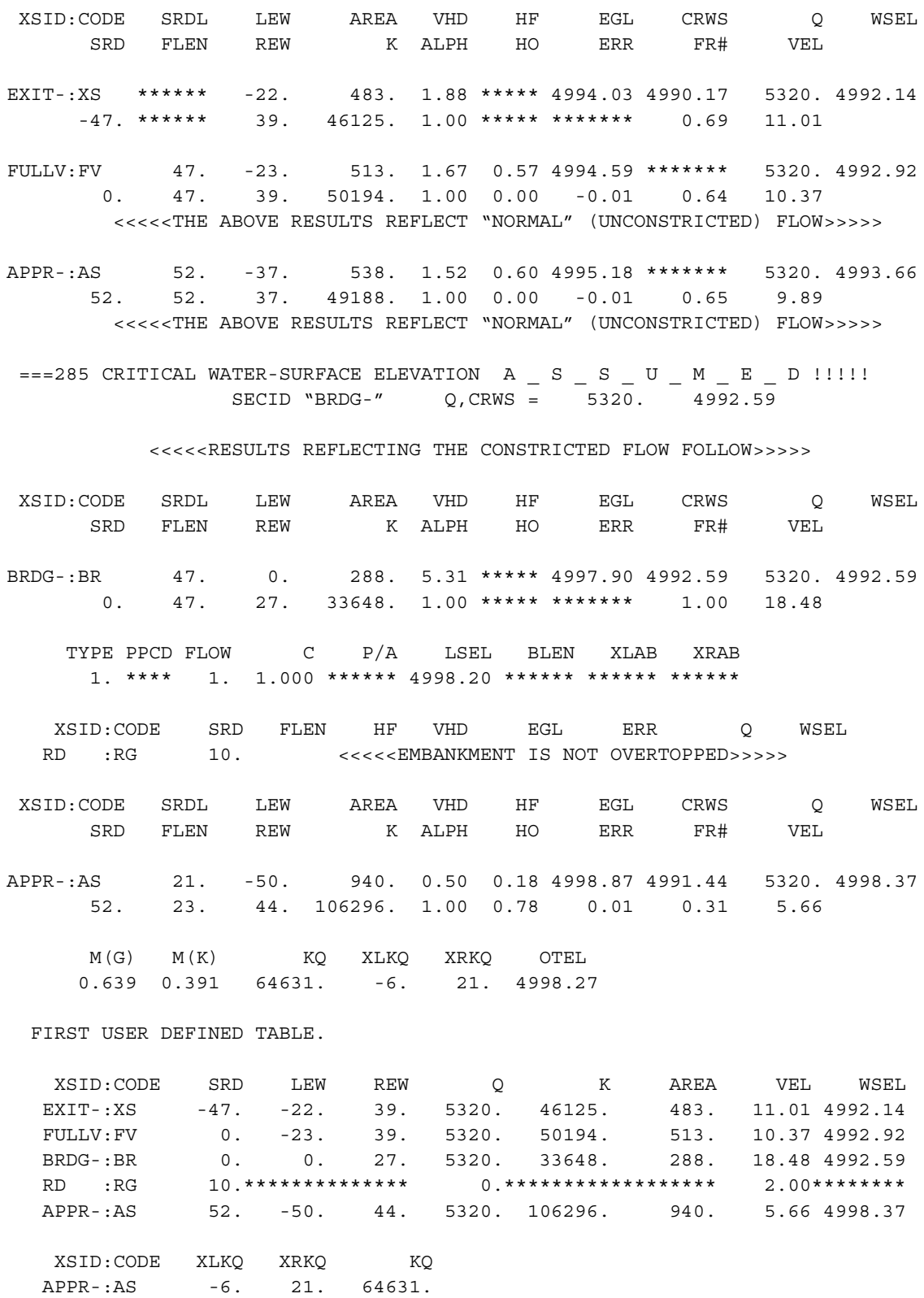

FIRST USER DEFINED TABLE.

\begin{tabular}{|c|c|c|c|c|c|c|c|c|}
\hline XSID : CODE & SRD & LEW & REW & $Q$ & $\mathrm{~K}$ & AREA & VEL & WSEL \\
\hline EXIT- : XS & -47 & -22 & 39. & 5320. & 46125 . & 483 & 11.01 & 4992.14 \\
\hline FULLV : FV & 0 & -23 & 39. & 5320. & 50194 & 513. & 10.37 & 4992.92 \\
\hline BRDG- : BR & 0 & 0 & 27. & 5320. & 33648 . & 288 & 18.48 & 4992.59 \\
\hline$:$ RG & \multicolumn{3}{|c|}{ 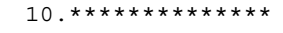 } & \multicolumn{3}{|c|}{ 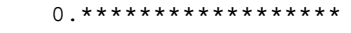 } & $2.00 *$ & 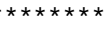 \\
\hline APPR- : AS & 52. & -50 & 44. & 5320. & 106296 & 940 & 5.66 & 4998.37 \\
\hline XSID : CODE & XLKQ & XRKQ & & & & & & \\
\hline A & -6 & 21 & 631 & & & & & \\
\hline
\end{tabular}

SECOND USER DEFINED TABLE.

\begin{tabular}{|c|c|c|c|c|c|c|c|c|c|}
\hline XSID : CODE & CRWS & FR\# & YMIN & YMAX & $\mathrm{HF}$ & $\mathrm{HO}$ & VHD & EGL & WSEL \\
\hline EXIT-:XS & 4990.17 & 0.69 & 4981.21 & $5006.22 *$ & *** & $\star \star \star$ & 1.88 & 4994.03 & 4992.14 \\
\hline FULLV : FV & 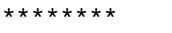 & .64 & 4981.50 & 5006.51 & 0.57 & 0.00 & 1.67 & 4994.59 & 4992.92 \\
\hline BRDG- : BR & 4992.59 & 1.00 & 4980.59 & $4998.33 *$ & 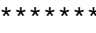 & $\star \star \star \star \star ~$ & 5.31 & 4997.90 & 4992.59 \\
\hline : RG & 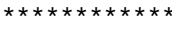 & 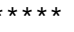 & 4999.72 & $5009.16 *$ & $* *$ & 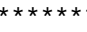 & $\star \star \star *$ & $\star \star \star \star *$ & $\star \star \star *$ \\
\hline PPR-: AS & 4991.44 & 0.31 & 4982.06 & 5009.47 & 0.18 & 0.78 & 0.50 & 4998.87 & 4998.37 \\
\hline
\end{tabular}




\section{APPENDIX C:}

\section{BED-MATERIAL PARTICAL-SIZE DISTRIBUTION}




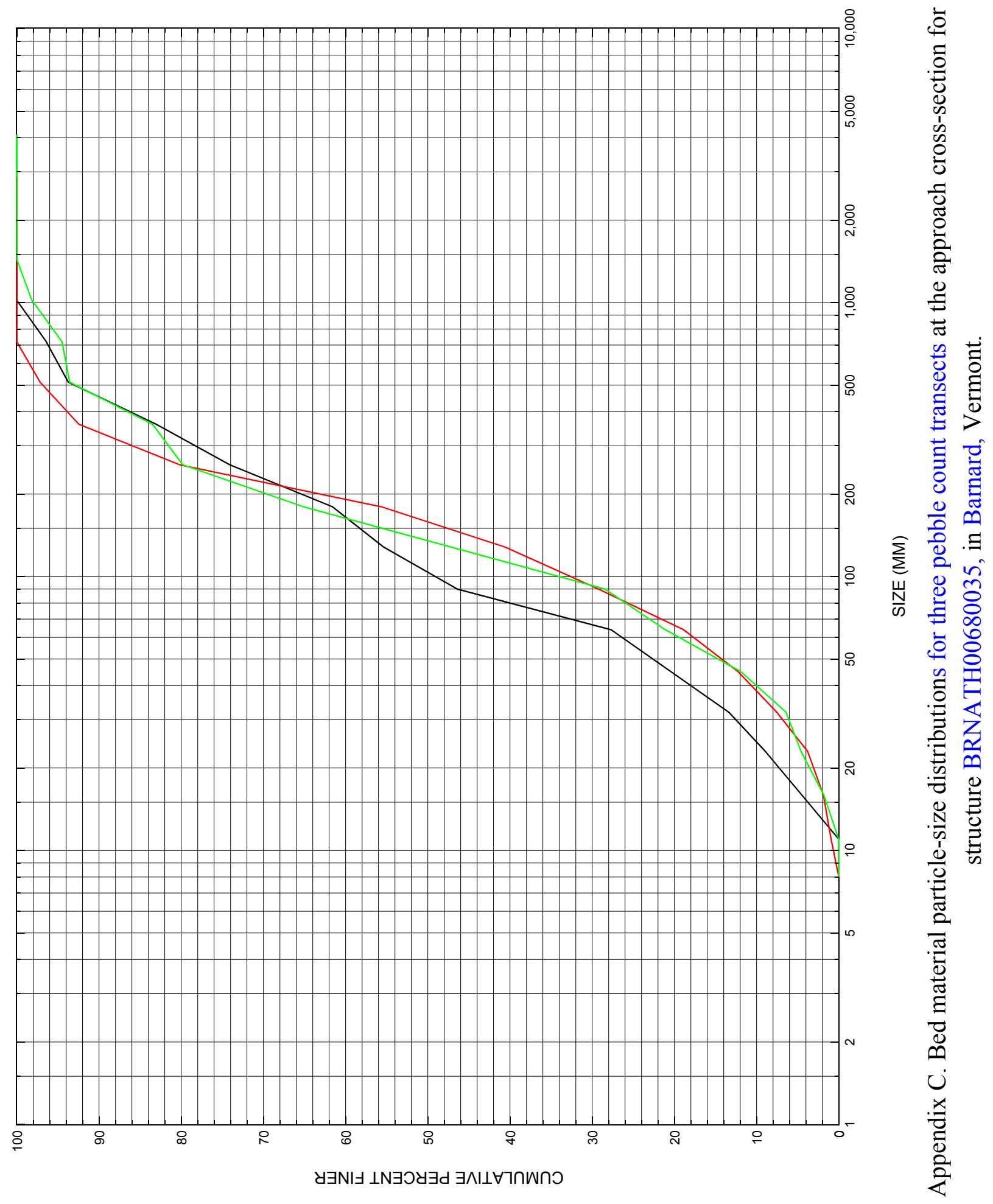




\section{APPENDIX D: \\ HISTORICAL DATA FORM}

